TAMAS BERTA

E-mail: berta.tamas@kti.hu

Division for Road Safety and Traffic Engineering

ÁDÁM TÖRÖK, Ph.D.

E-mail: torok.adam@kti.hu

Division for Transport Policy and Economics

KTI - Institute for Transport Sciences

Than Karoly 3-5, H-1111 Budapest, Republic of Hungary
Traffic on Motorways

Preliminary Communication

Accepted: Mar. 11, 2009

Approved: Feb. 02, 2010

\title{
TRAVEL TIME REDUCTION DUE TO INFRASTRUCTURE DEVELOPMENT IN HUNGARY
}

\begin{abstract}
The main scope of this paper is to present the formulation and visualization of shortening travel time in road transport due to the improvement of road network in Hungary. The formulation of the travel time based model has been developed by the authors. The paper also presents the demonstration of the results. The approach followed is quite innovatory in terms of visualization. The travel times were taken into account as opposed to geographical distances. Also, graph theory is used in order to calculate the matrix of "travel time" distances. The data from more than 30 cities were included in the model so as to make it quite representative for Hungary.
\end{abstract}

\section{KEYWORDS}

road transportation, reduction of travel time, positive external effect

\section{INTRODUCTION}

The aim of this paper is to present the travel time shortening due to the improvement of road transport infrastructure development in Hungary. The duties of State Motorway Management Company are the operation and maintenance of the parts of Hungary's high speed road network under its management, as well as the control of road-use authorization on toll sections [1]. To put it in numbers, this means managing of $666.5 \mathrm{~km}$ of motorways and $129.1 \mathrm{~km}$ of other roads, as well as $301.4 \mathrm{~km}$ of junction access and exit roads and the slip roads leading to motorway services, 113 rest areas themselves, and over 1000 separate bridge sections (Figure 1). On $555.1 \mathrm{~km}$ of the motorways managed by the company all the motor-vehicle categories have to pay toll, and on $69.5 \mathrm{~km}$ only those vehicles with a total weight of over 3.5 tons are liable for the charge.

\section{TRAVEL TIME REDUCTION MODELLING}

For the analyses and calculation of the model, the travel times between the cities were needed. The travel time variable is a good operational measure of effectiveness of traffic systems [2]. For greater accuracy of the results the actual travel time has been calculated with the usage of motorway system and without the usage of motorway system as opposed to the "geographic" (or straight line) distances. In mathematics and computer science, graph theory is the study of graphs that are mathematical structures used to model pairwise relations between objects from a certain collection [3]. A "graph" in this context refers to a collection of vertices and a collection of edges that connect pairs of vertices [4]. In our case we have the vertices as ports and the edges as routes between them. A graph may be undirected, meaning that there is no distinction between the two vertices associated with each edge, or its edges may be directed from one vertex to another. In the Euclidean space, the distance between two points is given by the Euclidean distance (2norm distance). For point $A\left(a_{1}, a_{2}, \ldots, a_{n}\right)$ and point $B$ $\left(b_{1}, b_{2}, \ldots, b_{n}\right)$ the distance between $A$ and $B$ is defined as 2-norm distance given by (1):

$d_{A B}=\sqrt{\left(\sum_{i=1}^{n}\left|a_{i}-b_{i}\right|^{2}\right)}$

In the Cartesian coordinates, the distance between two points is the length of the line segment between them (2):

$d_{i j}=\sqrt{(\Delta x)^{2}+(\Delta y)^{2}}=\sqrt{\left(x_{j}-x_{i}\right)^{2}+\left(y_{j}-y_{i}\right)^{2}}$

where $\left(x_{i}, y_{i}\right)$ are the coordinates of starting and $\left(x_{j}, y_{j}\right)$ are the coordinates of ending points of measurement and vice versa.

This gives the distance between two points as measured with a ruler (straight line). When building a city distance model the problem lies in the fact that the 2-norm "Cartesian" distance does not model the real- 


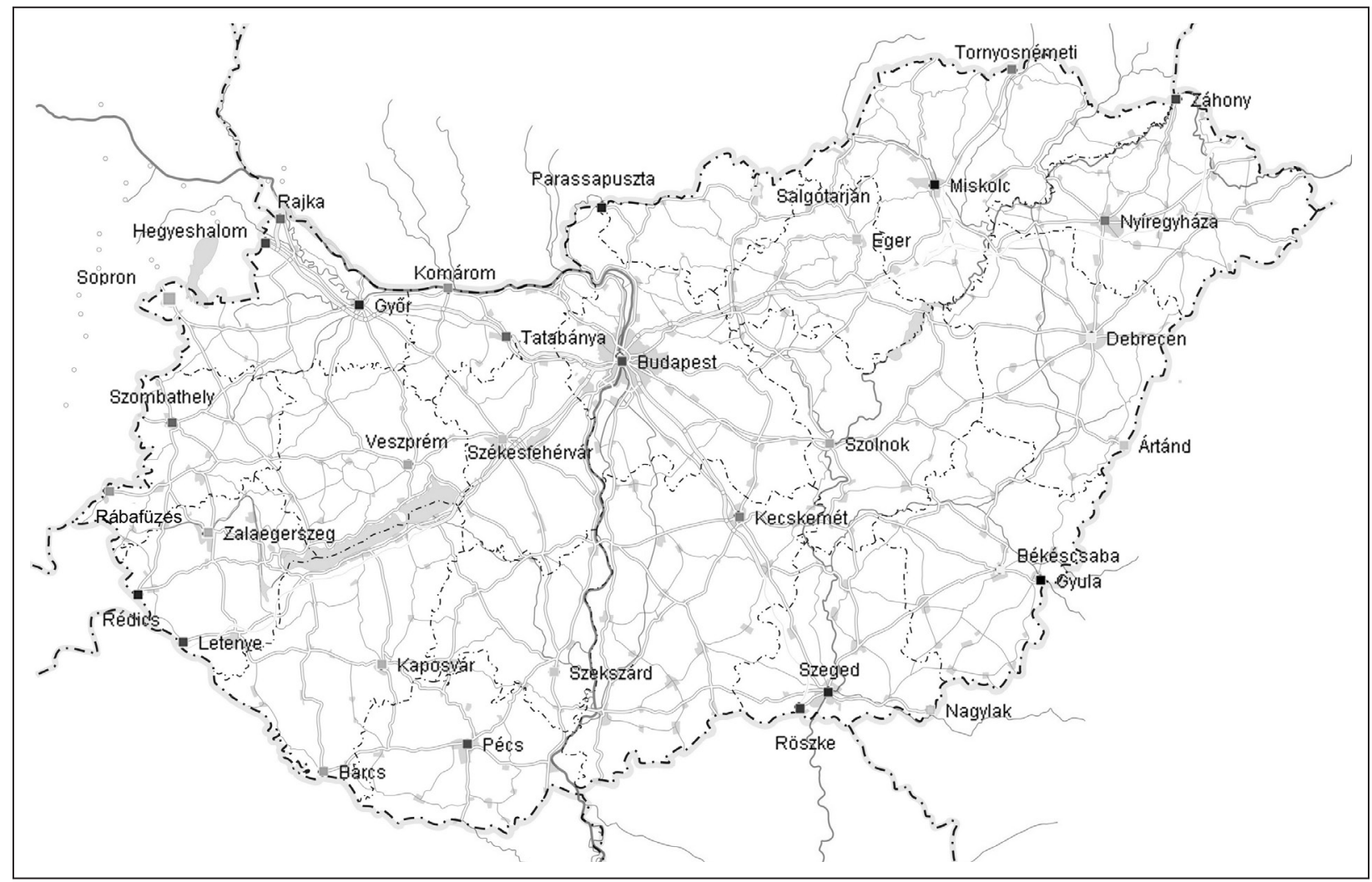

Figure 1 - Geographical map of Hungary

Source: Eötvös University, Department of Cartography and Geoinformatics, Laszlo ZENTAI, 2000

ity, because road transportation does not necessarily take the "shortest" path, as it depends on the infrastructure. That is the reason why the "Cartesian" distance was changed to "travel time" distance. "Travel time" distance describes the elapsed time between cities $i$ and $j$, by the route between them being either a motorway system or a non-motorway system. The "travel time" distance matrix $\underline{\underline{ } \underline{D}}$ between $m$ cities is given by:

$$
\underline{\underline{\underline{D}}}=\left[\begin{array}{ccc}
0 & r d_{1 j} & r d_{1 j} \\
r d_{1 j} & 0 & r d_{j m} \\
r d_{1 m} & r d_{j m} & 0
\end{array}\right]
$$

where ${ }_{r} D$ is a symmetric and square matrix, $r d_{i j}$ is the travel time distance between cities $i$ and $j$ and $r$ is a system parameter (motorway or non-motorway system).

The number of pairs of points $\frac{m(m-1)}{2}$ is the number of independent elements in the travel time distance matrix. In order to build up a graph from the travel times, the relative coordinates of the cities have been calculated. Multidimensional scaling (MDS) was used, which is a set of related statistical techniques often used in data visualization. MDS is a special case of ordination. An MDS algorithm starts with a matrix (matrix of travel time distances in this case), and then assigns a "location" of each vertex in a low-dimensional space suitable for graphing. Relation (4) describes the matrix $r \underline{\underline{ }}$ as a matrix of Euclidian distances based on the relative coordinates of ports (vertices) in the graph.

This is based on the same method as the way in which the computer calculates the place of vertices or cities compared to other vertices or cities. Since we used an MDS algorithm, relation (4) and the travel time distance between the cities, instead of the Euclidean ones, we had to compare the observed distances with the calculated data from MDS, in order to make sure our above model is valid. Measuring "the goodness-offit" was therefore necessary. The most common measure used to evaluate how well (or how poorly) a particular configuration reproduces the observed data (in this case the distance matrix) is the so called "stress measure". The raw "stress value" $\varphi$ of configuration (5) is defined by:

$\varphi=\sum_{i, j=1}^{m}\left[r d_{i j}-f\left(\delta_{i j}\right)\right]^{2}$

where ${ }_{r} d_{i j}$ stands for the reproduced distances from relative coordinates $\left\{\left(r_{k}, r y_{k}\right), k=1, \ldots m\right\}, \delta_{i j}$ are the 

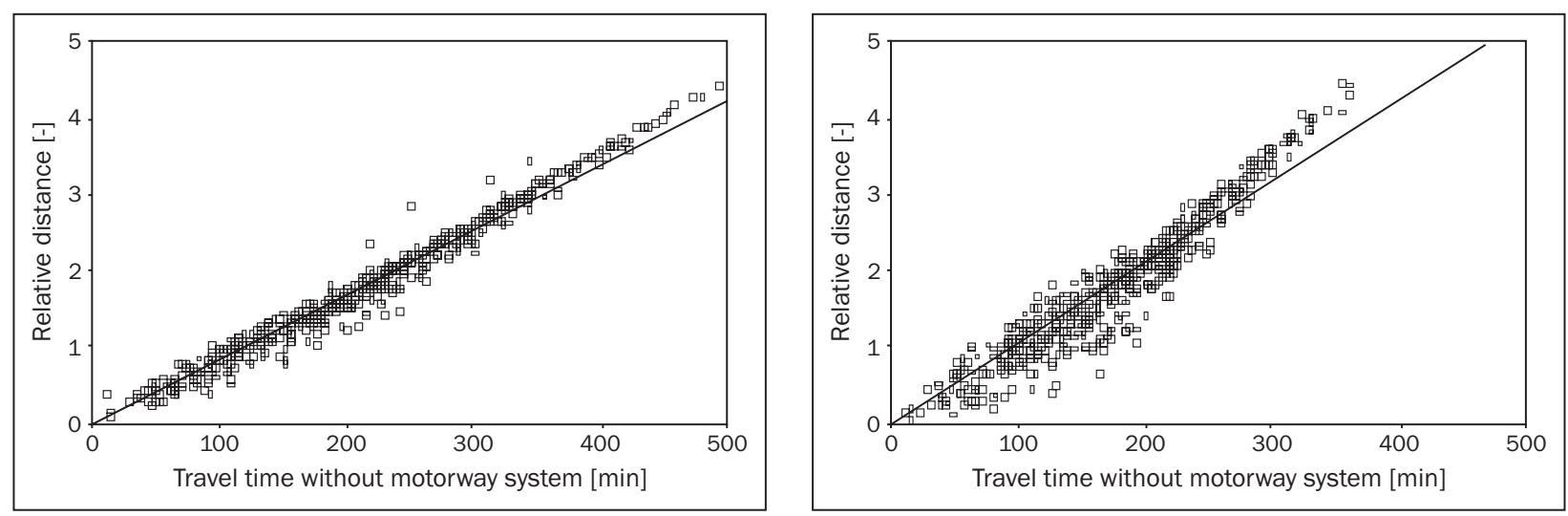

Figure $2 a$ and $2 b$ - Shepard diagram of transformation between ${ }_{r} d_{i j}$ and $\delta_{i j}$ with $(2 a)\left(R^{2}=0.89\right)$ and without $(2 b)\left(R^{2}=0.863\right)$ the motorway system

input data (i.e., observed average travel time without the possibility of traffic jam) and $f\left(\delta_{i j}\right)$ indicates a monotone transformation of the observed data. Transformation $f$ transforms the travel time that has been measured between the cities using either motorway system or non-motorway system into a relative distance. A monotone transformation is a transformation that preserves the inequalities of its arguments, i.e. if $f$ is a monotone transformation, then: if $x>y$, then $f(x)>f(y)$. We have calculated relative coordinates of vertices (cities) from the travel time between them. From the relative coordinates a relative distance can be calculated. The relative distance was compared with the observed travel time. Thus, the smaller the stress value, the better is the fit of the reproduced distance matrix that is based on the relative coordinates to the observed distance matrix that is based on the travel time (in this case the value of $\varphi$ was 0.1 [-] for motorway system and 0.05 [-] in the case when motorway system does not exist). Measurement unit [-] is a relative unit distance followed from the relative coordinates and it presents the distance which can be reached by driving for an hour at an average velocity. If the matrix of reproduced distances is the same as the matrix of values $\mathrm{f}\left(\delta_{\mathrm{ij}}\right)$, the difference $\varphi$ would be zero.

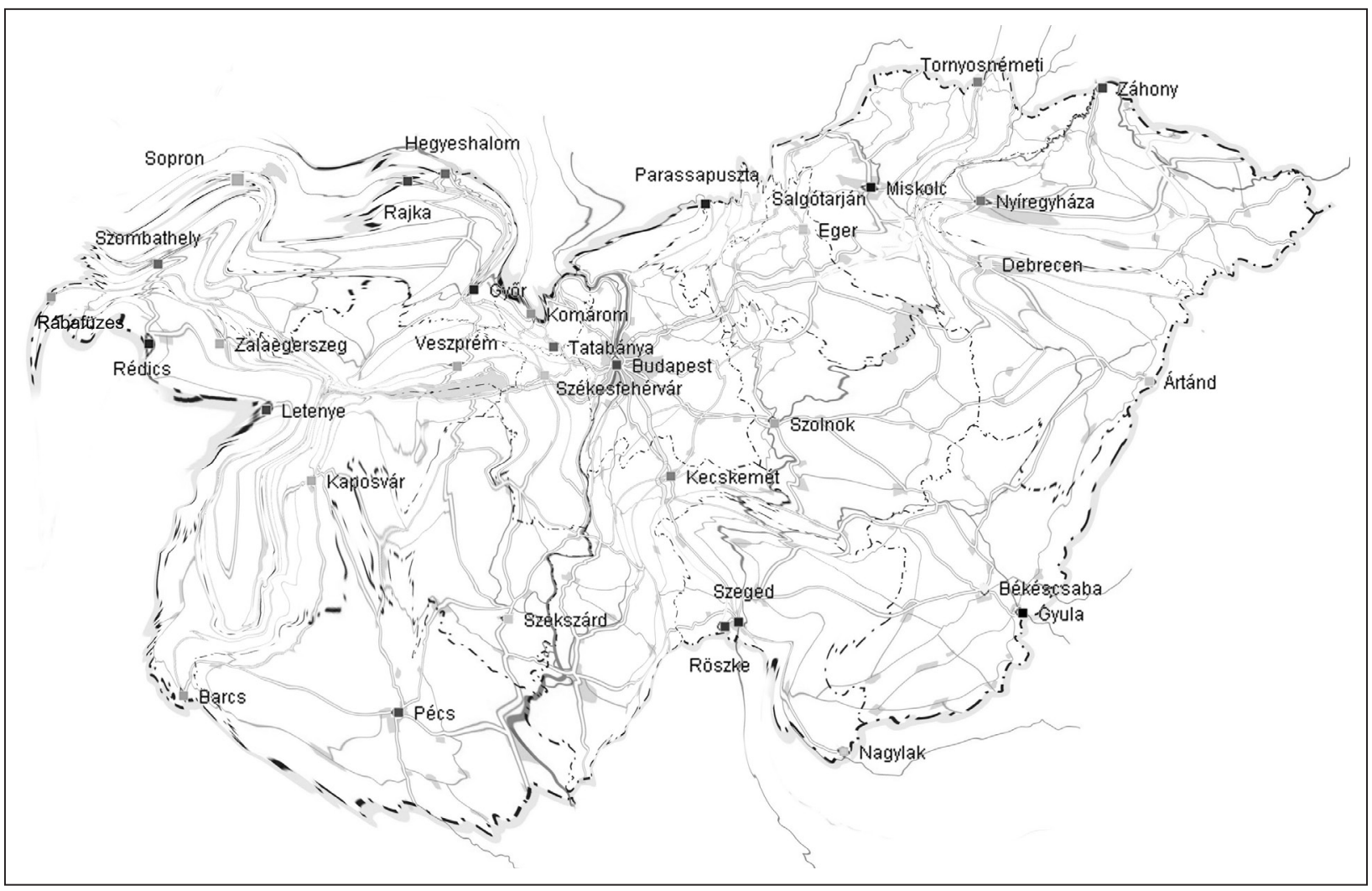

Figure 3 - Modified map of Hungary according to travel time with motorway system 


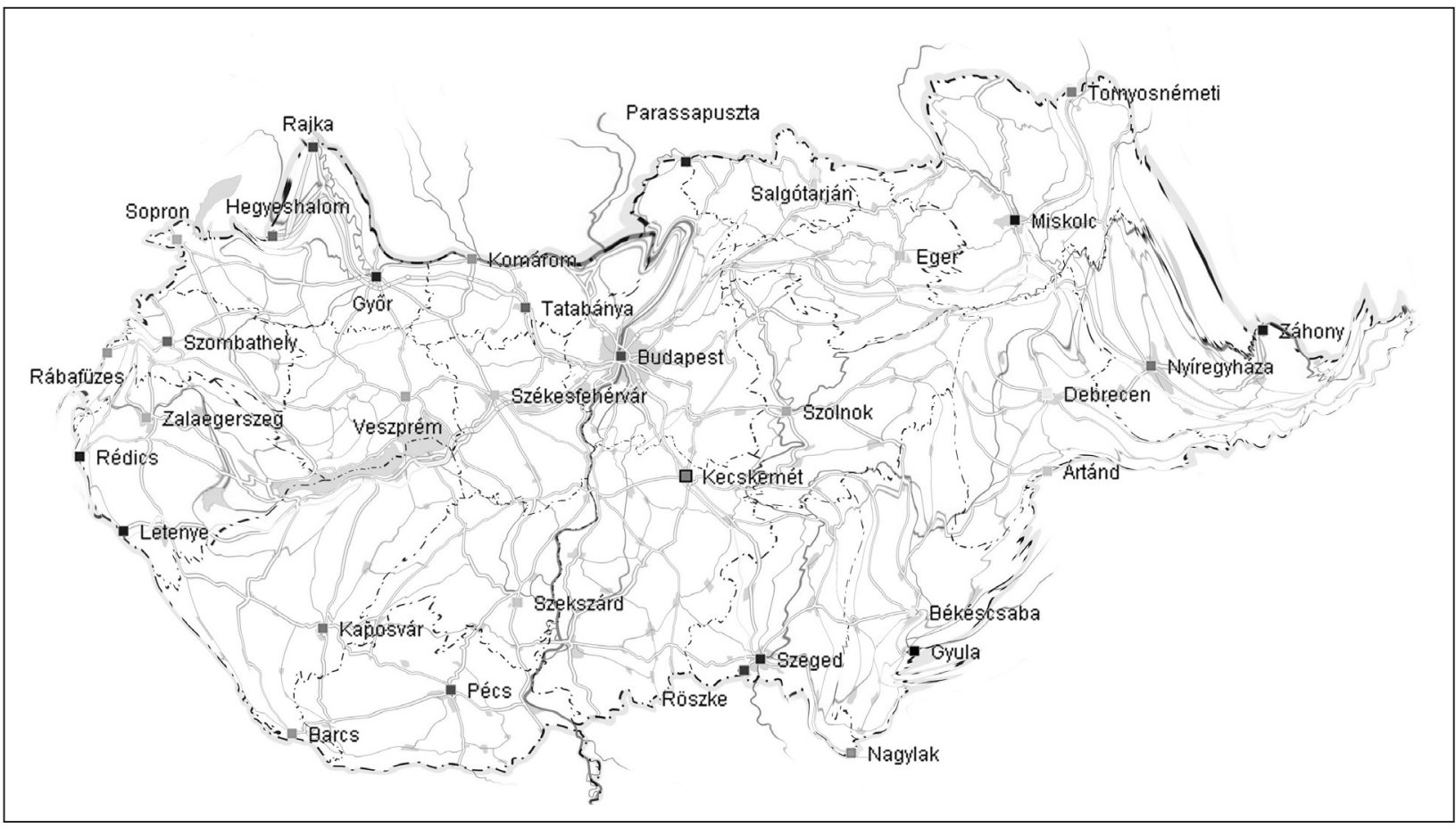

Figure 4 - Modified map of Hungary according to travel time without the motorway system

As an additional way of checking, a Shepard diagram was produced, i.e. a plot between the reproduced distances from relative coordinates plotted on the vertical $(Y)$ axis versus the measured time plotted on the horizontal $(X)$ axis. This is shown in Figures 2a and $2 \mathrm{~b}$.

As can be seen from Figures $2 a$ and $2 b$ the transformation of distances into a graph has a very low error. This line represents the so- called $D$-hat values, that is, the result of the monotone transformation $\mathrm{f}\left(\delta_{\mathrm{ij}}\right)$ of the input data. If all the reproduced distances fall onto the step-line, then the rank-ordering of distances (or similarities) would be perfectly reproduced by the respective solution (dimensional model). Deviations from the step-line indicate a lack of fit. So the new "relative" position of the cities under consideration as based on travel time distances, and the graph theory representation are different than the known geographic one as shown in Figures 3 and 4. In both cases, for motorway and non-motorway system the average velocity is different, so that Figures 3 and 4 are in different scales.

As can be seen from Figures 3 and 4 the two graphs are different which is in line with the expectations.

The graph that is based on geographical distances is not similar to the graph that is based on the travel time distances with the motorway system nor with travel time distances without the motorway system.

\section{CONCLUSIONS}

The transport globally, and particularly in Hungary is likely to increase by high annual rates. This is justified by a number of factors, such as the enlargement of the EU with 2 new members in 2008, and the increasing share of logistics and transport services in the GDPs of the countries in the central EU area. Hungary has recognized the growing importance of transport and logistics, because its geopolitical position provides advantages of such kind of services. Thus, a dedicated set of policy measures for strengthening of the market position of the Hungarian logistics infrastructures and service providers has been introduced for the last years [5]. Due to the position of Hungary, the transit traffic is very high so it is vital to examine the travel times in Hungary. In this study the investigation was focused on the reduction of travel time due to the rapid road infrastructure development. The study showed that a well calibrated model for travel time can be built, and the results it produces are realistic. Such model can be subsequently used in the feasibility and planning studies for further infrastructure development. An innovative feature of the model developed by the authors is the use of travel time distance matrix combined with graph theory for the handling and visualisation of the data relating to road transport in Hungary. The model has been developed based on data taken from more than $\mathbf{3 0}$ cities in Hungary. 


\section{TAMAS BERTA}

E-mail: berta.tamas@kti.hu

Közlekedésbiztonségi és Forgalomtechnikai Tagozat

\section{Dr. ÁDÁM TÖRÖK}

E-mail: torok.adam@kti.hu

Közlekedéspolitikai és -gazdasági Tagozat

KTI - Közlekedéstudományi Intézet

Than Karoly 3-5, H-1111 Budapest, Magyar Köztársaság

\section{ABSZTRAKT}

\section{AZ UTAZÁSI IDÓ CSÖKKENÉSE A MAGYAR GYORSFORGALMI ÚTHÁLÓZATFEJLESZTÉS KÖVETKEZTÉBEN}

Cikkünk célja az gyorsforgalmi úthálózat fejlesztés következtében létrejövố utazási idố rövidülés matematikai modellezésének és megjelenitésnek bemutatása A matematikai model alapját egy honnan-hová utazási idő matrix képezi. A cikk továbbá tartalmazza az eredmények bemutatását, Cikkünkben az utazási idő és a földrajzi távolság között feszüló ellentétet próbáltuk gráf elméleti alapon feloldani. Az alapadatokat több mint 30 magyar város felhasználásával generálták a szerzők.

\section{KULCSSZAVAK}

közúti közlekedés, utazási idő rövidülése, pozitív externális hatás

\section{LITERATURE}

[1] Mészáros F.: Acceptability as an important precondition of transport policy implementation, with special regard to Hungary as a newly accessing country, Schriftenreihe der Deutschen Verkehrswissenschaftlichen Gesellschaft. Budapest, Magyarország, 2003.07.022003.07.06. Berlin, 2004.

[2] J.-S. Yang: Application of the Kalman filter to arterial travel time prediction: A special event case study, Control and intelligent systems, ISSN 1480-1752, 2007, vol. 35, no1, pp. 79-85.

[3] Giannopoulos, G., Aifadopoulou, G., Torok, A.: Port Choice Model for the Transshipment of Containers in Eastern Mediterranean, TRB 87th Annual Meeting. Washington, USA, 2008. pp. 25-40 . Paper \#08-1517.

[4] Dienstel, R.: Graph Theory, Springer-Verlag Heidelberg, New York 2005,

[5] Bokor, Z.: Hungary: role of the state in intermodal transport logistics services. Logistics and Transport Focus, vol. 9, no. 8, 2007, pp. 37-41. 